\title{
TRANSNATIONAL JUDICIAL AND NON-JUDICIAL REMEDIES FOR CORPORATE HUMAN RIGHTS HARMS: CHALLENGES OF AND FOR LAW ${ }^{1}$
}

\section{Sara L. Seck*}

This paper will consider whether the polycentric governance approach of the 2011 United Nations Guiding Principles on Business and Human Rights has the potential to achieve the goal of transnational corporate compliance with human rights responsibilities including, importantly, the goal of access to remedy and justice for those who have been harmed. The paper was initially written as a contribution to a conference at the University of Windsor entitled Justice Beyond the State: Transnationalism and Law. First, the paper examines understandings of "citizenship" and "non-citizenship" in relation to transnational corporate [TNC] accountability in the human rights context. Two distinct perspectives are explored: first, TNC citizenship and non-citizenship and the rights and responsibilities that flow from these; and second, citizenship and noncitizenship of victims of human rights violations in relation to rights of access to remedy. Together, these insights inform an understanding of the role that transnational law and legal pluralism beyond the state could serve in facilitating remedy for human rights violations. Specifically, the paper will conclude with reflections on what might be required for implementation of the UN Guiding Principles to achieve the goal of transnational corporate compliance and access to remedy for victims of rights violations.

Le présent document examinera si l'approche polycentrique en matière de gouvernance adoptée par les Principes directeurs relatifs aux entreprises et aux droits de l'homme, publiés par les Nations Unies en 2011, peut permettre de réaliser l'objectif de la conformité transnationale des entreprises aux responsabilités en matière de droits de la personne, notamment et surtout l'objectif de l'accès aux recours et à la justice pour les parties lésées. Au départ, le document avait été rédigé à titre de contribution à une conférence à l'Université de Windsor intitulée Justice Beyond the State: Transnationalism and Law. Le document se penche tout d'abord sur la compréhension des termes "citoyenneté » et "non-citoyenneté » en ce qui concerne la responsabilité transnationale des entreprises dans le contexte des droits de la personne. Deux perspectives distinctes sont étudiées : premièrement, la citoyenneté et la non-citoyenneté transnationales des entreprises et les droits et responsabilités qui en découlent; deuxièmement, la citoyenneté et la non-citoyenneté des victimes de violations des droits de la personne par rapport aux droits d'accès aux recours. Ensemble, ces perspectives éclairent une compréhension du rôle que le droit transnational et le pluralisme juridique

1 This paper was written as a contribution to the conference Justice Beyond the State: Transnationalism and Law, held at the Faculty of Law, University of Windsor, September 2013. The author would like to extend her thanks to the organizers, especially Professor Maureen Irish, for inviting her to participate in this stimulating conference. Thanks are also due to participants for their helpful comments and to an anonymous reviewer.

* Western Law 
au-delà de l'État pourraient jouer pour faciliter les recours en cas de violation des droits de la personne. En particulier, le document présentera en conclusion des réflexions sur ce qui pourrait être requis pour mettre en ouvre les Principes directeurs des Nations Unies de manière à réaliser l'objectif de la conformité transnationale des entreprises et de l'accès aux recours pour les personnes dont les droits ont été violés.

\section{INTRODUCTION}

The quest for access to remedy for alleged violations of human rights associated with transnational corporate conduct has received much attention due to recent developments at the United Nations Human Rights Council [UN HRC] under the 2005-2011 mandate of the Special Representative on Business and Human Rights. $^{2}$ Following extensive multi-stakeholder and regional consultations in which transnational corporations [TNCs] and their lawyers, ${ }^{3}$ among others, played a critical role, the UN HRC endorsed the Guiding Principles on Business and Human Rights: Implementing the United Nations "Protect, Respect and Remedy" Framework [Guiding Principles] in June 2011. ${ }^{4}$ The Guiding Principles are comprised of three "differentiated but complementary responsibilities": ${ }^{5}$ (1) the state duty to protect against human rights abuses by third parties, including business enterprises, through appropriate policies, regulation and adjudication; (2) the corporate responsibility to respect human rights, according to which business enterprises should act with due diligence to avoid infringing on the rights of others and to address adverse impacts with which they are involved; and (3) the need for greater access to remedy for victims of business-related abuse, both judicial and non-judicial. While the state duty to protect is firmly rooted in existing international human rights law, the corporate responsibility to respect is not, rather arising (at least in part) pragmatically, from the need for businesses to both seek and retain a "social license to operate", ${ }^{6}$ irrespective of whether a host state is in compliance with its own duty to protect human rights. Conceptualized as a polycentric governance framework, ${ }^{7}$ the Guiding Principles highlight the importance of both judicial and non-judicial remedy, including operational-level grievance mechanisms, as tools for closing the governance gaps created by globalization.

Yet, the extent to which state-based judicial mechanisms will in fact be enabled to provide meaningful and effective transnational remedy is inhibited by perceptions of illicit extraterritoriality (the

2 See generally, John G Ruggie, Just Business: Multinational Corporations and Human Rights (New York: WW Norton \& Co, 2013).

3 Sara L Seck, “Corporate Law Tools and the Guiding Principles for Business and Human Rights” in Manoj Kumar Sinha, ed, Business and Human Rights (Thousand Oaks, CA: Sage Publishers, 2013) 93.

4 Report of the Special Representative of the Secretary-General on the issues of human rights and transnational corporations and other business enterprises, John Ruggie, Guiding Principles on Business and Human Rights: Implementing the United Nations "Protect, Respect and Remedy" Framework, UNHRC, $17^{\text {th }}$ Sess, UN Doc A/HRC/17/31 (2011) [Guiding Principles].

$5 \quad$ Ibid at para 9.

6 Report of the Special Representative of the Secretary-General on the issues of human rights and transnational corporations and other business enterprises, John Ruggie, Protect, Respect and Remedy: A Framework for Business and Human Rights, UNHRC $8^{\text {th }}$ Sess, UN Doc A/HRC/8/5 (7 Apr 2008) at para 54.

7 Larry Catá Backer, “On the Evolution of the United Nations' 'Protect-Respect-Remedy' Project: The State, the Corporation and Human Rights in a Global Governance Context” (2011) 9 Santa Clara Journal of International Law 37. 
"e-word") ${ }^{8}$ built into multiple legal doctrines designed - intentionally or not - to shield transnational corporate actors from legal accountability. These doctrines include those arising out of common understandings of sovereignty and raised in relation to the exercise of home state jurisdiction - whether prescriptive, adjudicative or enforcement - as well as those arising out of common understandings of corporate legal personality and raised in relation to the application of legal liability to transnational or multinational enterprises - whether in domestic or "foreign" courts. The challenges and misconceptions associated with the doctrines that inhibit transnational legal remedy have created pressure to develop and enhance the effectiveness of both state-based and non-state-based non-judicial remedy, including company-level grievance and remedy mechanisms. This dynamic is evident in the Guiding Principles. However, one unanswered question is how to reconcile the increasing prevalence of transnational nonjudicial mechanisms with the legal systems of host states, and further, with the right of those whose human rights have been violated to seek both remedy and accountability.

This paper will consider whether the polycentric governance approach of the Guiding Principles has the potential to achieve the goal of transnational corporate compliance with human rights responsibilities including, importantly, the goal of access to remedy for those who have been harmed. Before delving into an analysis of the remedy provisions under the Guiding Principles, however, the paper will first examine understandings of "citizenship" and "non-citizenship" in relation to transnational corporate accountability in the human rights context. ${ }^{9}$ Two distinct perspectives will be explored: first, TNC citizenship and non-citizenship and the rights and responsibilities that flow from these; and second, citizenship and non-citizenship of victims of human rights violations in relation to rights of access to remedy. Together, these insights will inform an understanding of the role that transnational law and legal pluralism beyond the state could serve in facilitating remedy for human rights violations. Specifically, the paper will conclude with reflections on whether implementation of the Guiding Principles could achieve the goal of transnational corporate compliance and access to remedy for victims of rights violations.

\section{CORPORATE CITIZENSHIP AND NON-CITIZENSHIP, STATE DUTIES}

It is true that increasingly policy documents, advocacy groups and scholarly literature speak of the importance of corporations taking seriously their responsibility as "citizens". ${ }^{10}$ Indeed, the emergence of the idea of corporate social responsibility [CSR] is indicative of the view that the interests of society and businesses merge, whether voluntarily undertaken by businesses that embrace enlightened interpretations of shareholder value, or due to the increasing prevalence of legal "drivers" of CSR. ${ }^{11}$ In law, however, the meaning of corporate citizenship is less obvious, particularly if a transnational

8 Sara L Seck, "Kiobel and the E-word: Reflections on Transnational Environmental Responsibility in an Interconnected World" (5 July 2013) online: Law at the End of the Day <http://lcbacker-blog.blogspot.ca/2013/07/sara-seck-on-kiobeland-e-word.html> [Seck, "Kiobel"].

$9 \quad$ This exploration is inspired by questions posed to contributors to the Justice Beyond the State conference.

10 See for e.g. Corporate Knights' rankings of best Canadian corporate citizens, online: Corporate Knights $<$ http://www.corporateknights.com/report/2012-best-corporate-citizens-canada>.

11 See generally, Michael Kerr, Richard Janda \& Chip Pitts, Corporate Social Responsibility: A Legal Analysis (Markham ON: LexisNexis, 2009); D McBarnet, A Voiculescu \&Tom Campbell, eds, The New Corporate Accountability: Corporate Social Responsibility and the Law (Cambridge: Cambridge University Press, 2007). 
perspective is embraced.

It is important to first understand what a corporation - transnational corporation [TNC], multinational enterprise [MNE] - is. ${ }^{12}$ Understandings of corporate legal personality depend in part on whether the conceptualization endorsed is that of separate individual entities incorporated in multiple states (entity theory) or that of a single TNC or MNE operating across borders (enterprise theory). ${ }^{13}$ While legally corporate entity theory generally prevails, social understandings of large corporate enterprises are based upon the enterprise as a whole. ${ }^{14}$ Thus we speak of "Nike" or "Starbucks" rather than unpacking and distinguishing the numerous individual entities that contribute to the corporate enterprise as a whole, whether as legally affiliated companies or contractors. Moreover, corporations are ultimately a collective of individuals who participate in the enterprise in many different capacities, including as directors, officers, employees or agents. ${ }^{15}$

At first glance, understanding the meaning of corporate citizenship appears inextricably linked to understandings of nationality. Yet corporate nationality is a challenging concept given the mainstream view under international law that states are free to determine the criteria for corporate nationality within their own laws. ${ }^{16}$ While state practice with regard to corporate nationality diverges, it is common for nationality to be accorded on the basis of jurisdiction of incorporation in common law countries, while in civil law nationality is often conferred on the basis of siège sociale - where the business or management is carried out. As corporations frequently incorporate in one jurisdiction for tax or other purposes but undertake business or management in another jurisdiction, it is not uncommon for a corporation to have more than one nationality. Moreover, state regulatory practices diverge in different contexts, applying laws on the basis of incorporation in one context, then implicitly adopting a seat of management test when applying law on the basis of a control test that references owners, managers or operators. ${ }^{17}$ Beyond this, each individual who contributes to the collective corporate enterprise has a nationality, if not more than one. Unpacking a single legal test for corporate nationality - and thus arguably corporate citizenship - appears not to be a simple task.

Where the conduct being regulated is undertaken by a TNC or MNE, corporate nationality becomes even more complex. While a state may apply its law directly to a corporate national with a branch or office in another state, it may not as a rule (under doctrines of international law) apply its law directly to a foreign affiliate set up as a separate legal entity under the laws of the host state. Complexity increases given the prevalence of international joint ventures with several parent company shareholders of

12 TNC and MNE will be used interchangeably in this paper.

13 See Jennifer A Zerk, Multinationals and Corporate Social Responsibility (Cambridge: Cambridge University Press, 2006) at 54-56; Peter Muchlinski, Multinational Enterprises and the Law, (Oxford: Blackwell, 1995) at 328-9.

14 See e.g. discussion of Gap Inc in Larry Catá Backer, "Multinational Corporations As Objects and Sources Of Transnational Regulation” (2007-2008) 14 ILSA J Int'l \& Comp L 499 at 509-521. [Cata Backer, “Gap”] However, in some jurisdictions such as India, the idea of multinational corporate enterprise liability is evident. See Upendra Baxi, "Mass Torts, Multinational Enterprise Liability, and Private International Law” (1999) 276 Rec des Cours 297, at 399401 ["Mass Torts”].

15 Sara L Seck, “Collective Responsibility and Transnational Corporate Conduct”, in Richard Vernon \& Tracy Isaacs, eds., Accountability for Collective Wrongdoing (Cambridge University Press, 2011) 140, at 142-149.

16 This material is drawn from Sara L Seck, "Home State Responsibility and Local Communities: The Case of Global Mining” (2008) 11 Yale Human Rts \& Dev LJ 177 at 187-189. See also generally, Jennifer Zerk, supra note 13 at $146-$ 151.

17 Seck, ibid; Zerk, ibid. 
different nationalities investing in a company incorporated in the host state. ${ }^{18}$ And complexity increases further if a distinction is drawn between "investment company shareholders" and "operational parent company shareholders". ${ }^{19}$ Of course the corporate form is but one business structure of the global economic order. Moreover, the line between "state" and "corporation" is not always an easy one to draw when account is given to the important role played by state-owned enterprises (SOEs) in the global economy, and the history of trading companies in the colonization process is remembered. ${ }^{20}$ Crucially, though, even where "home" states could apply laws to prevent and remedy human rights harms in foreign host states (by imposing a course of conduct on effectively controlled subsidiaries through the parent company, or influencing behaviour through minority shareholdings), they generally choose not to, citing fear of infringing the sovereignty of the host state or competitive disadvantage. ${ }^{21}$ This reality informed the ultimate lack of clarity surrounding the jurisdictional scope of the state duty to protect under the Guiding Principles, including the hotly debated content of Principle 2, which culminated in the following compromise:

States should set out clearly the expectation that all business enterprises domiciled in their territory and/or jurisdiction respect human rights throughout their operations. ${ }^{22}$

The choice to focus on the "domicile" of "business enterprises" rather than the "nationality" of "corporations" in this Principle appears designed to overcome the legal limitations of separate legal personality of corporate entities. This is to be contrasted with the language of Principle 1, understood by many as focused exclusively on the duty of the host state:

States must protect against human rights abuse within their territory and/or jurisdiction by third parties, including business enterprises. This requires taking appropriate steps to prevent, investigate, punish and redress such abuse through effective policies, legislation, regulations and adjudication. ${ }^{23}$

18 Seck, ibid; Zerk, ibid.

19 See Robin Hansen, “Defining the Multinational Enterprise in International Law: A Review of State Initiatives” draft paper prepared for June 2013 Conference of the International Law Association's Committee on Non-State Actors, Vancouver, BC (on file with author; forthcoming as chapter in edited book, Brill) .

20 On SOEs, see generally OECD Guidelines on Corporate Governance of State-Owned Enterprises (OECD, 2005), online: OECD <http://www.oecd.org/corporate/ca/corporategovernanceofstate-ownedenterprises/34803211.pdf>; On trading companies and colonization, see Antony Anghie, Imperialism, Sovereignty and the Making of International Law (New York: Cambridge University Press, 2005) at 67-69.

21 See for e.g. discussion of the Canadian state’s engagement with global mining in Sara L Seck, "Canadian Mining Internationally and the UN Guiding Principles for Business and Human Rights” (2011) 49 Can YB Int'l Law 51 [Seck, "Canadian Mining”]. But see Sara L Seck "Unilateral Home State Regulation: Imperialism or Tool for Subaltern Resistance?” (2008) 46 Osgoode Hall LJ 565 (discussing the history leading to the current consensus on home state antibribery regulation) [Seck, "Unilateral Home”]. Audrey Macklin \& Penelope Simons, The Governance Gap: Extractive Industries, Human Rights and Home State Advantage (London: Routledge: 2013)

22 Guiding Principles, supra note 4 at Principle 2. See Seck, "Canadian Mining” supra note 21 at 107-109 (describing submissions made in relation to Principle 2).

23 Guiding Principles, supra note 4 at Principle 1; Seck, “Canadian Mining” supra note 21 at 111 (noting that if Principle 1 is read together with Principle 25, a more expansive interpretation of the jurisdictional scope of Principle 1 emerges). 
A key question here is how to understand "jurisdiction" - a question that will remain unanswered for now. For the purpose of this paper, however, the crucial point is that the complexity surrounding corporate nationality and home state jurisdiction facilitates a situation in which business enterprises may benefit from "home" state support for operations abroad (including from export credit agencies, trade missions abroad, development agency support of CSR initiatives, tax rules, etc). ${ }^{24}$ Yet at the same time, the same business enterprises may argue in transnational corporate accountability litigation brought in home state courts by foreign plaintiffs that either the litigation should be dismissed to a jurisdiction with a closer connection (that of the local subsidiary or affiliate) under private international law doctrines (most notably in non-EU common law jurisdictions forum non conveniens [FNC]), ${ }^{25}$ or, if FNC is not argued, that the litigation should be dismissed as disclosing no reasonable cause of action because the allegations against the subsidiary or those it contracts with cannot legally be conceptualized as the responsibility of the parent company, not being captured by traditional "veil-piercing" exceptions or doctrines of vicarious liability. ${ }^{26}$ This line of argument is often successful but perhaps increasingly failing, at least at a preliminary stage, although consideration of the substance of legal claims in home state courts remains to date quite rare. ${ }^{27}$

At the same time, the historic laws of diplomatic protection as applied to foreign investors has over the years created a situation in which, due to their claimed status as non-citizens of the states in which they invest, foreign investors have rights under bilateral and regional investment treaties and investorstate contracts that enable then to sue host states for expropriation of investment opportunities when host states choose to legislate in the public interest to protect human rights and the environment. These host states fall victim to doctrines or "disciplines" such as national treatment, most favoured nation, and compensation for expropriation that benefit investors seeking predictability and security. ${ }^{28}$ Curiously, however, in the investment arbitration context the corporate veil is commonly said to be "irrelevant with respect to the rights of indirect shareholder companies to launch investment claims." ${ }^{29}$ This is because

24 Seck, “Canadian Mining” supra note 21 at 66-75 (discussing Bill C-300).

25 Ibid; see also Sara L Seck, "Environmental Harm in Developing Countries Caused by Subsidiaries of Canadian Mining Corporations: The Interface of Public and Private International Law” (1999) 37 Can YB Int'l Law 139 [Seck, "Enviromental Harm”]. Many cases can be cited for this, most notoriously the Bhopal case much discussed in the writings of Upendra Baxi including: Upendra Baxi, Inconvenient Forum and Convenient Catastrophe (Bombay: NM Tripathi, 1986); Baxi, “Mass Torts”, supra note 14; International Campaign for Justice in Bhopal, online $<$ http://bhopal.net/>.

26 See Seck, “Canadian Mining”, supra note 21, at 64-65 for examples, including Piedra v Copper Mesa Mining Corp, 2010 ONSC 2421, aff'd 2011 ONCA 191, 332 DLR (4th) 118.

27 For a recent unsuccessful attempt to seek early dismissal, see the Hudbay litigation, Choc v Hudbay Minerals Inc, 2013 ONSC, 1414. For examples from other jurisdictions, see Chandler v Cape Plc, [2012] EWCA Civ 525; Milieudefense et al v Shell et al, HA ZA 09-1580 (2013). But see infra for a brief discussion of the Kiobel litigation under the US Alien Tort Statute.

28 On this see Kyla Tienhaara, The Expropriation of Environmental Governance: Protecting Foreign Investors at the Expense of Public Policy, (Cambridge: Cambridge University Press, 2009); and Gus van Harten, Investment Treaty Arbitration and Public Law (Oxford: Oxford University Press, 2007). However, more recently, some states are resisting this dynamic, as evidenced by states that have pulled out of ICSID. See Nicolas Boeglin, "ICSID and Latin America: Criticism, withdrawal and the search for alternatives (3 December 2013), online: Bretton Woods Project <http://www.brettonwoodsproject.org/2013/12/icsid-latin-america/>.

29 Hansen, supra note 19. 
the definition of investment in many investment treaties includes “'shares' without qualifying the level of ownership required." 30 Accordingly, "many corporate investors have launched claims in relation to investments that the investor owns through other corporations." 31

While I have suggested above that "nationality" might perhaps be equated with "citizenship", this may not in fact be the best or only approach. As Karen Knop has astutely observed, there is a private side to citizenship that can be found in private international law or conflict of laws, where there is "the normality of encountering the foreign”. ${ }^{32}$ Knop notes:

"Private international law starts with a different set of assumptions about the interaction of states. It begins with the idea that there will be individual comings and goings across borders. The very raison d'être of private international law is that the state will inevitably contain foreigners of different kinds - not only those who aspire to citizenship, but also those who are de passage, traders, exiles, expatriates, transmigrants - and this will necessarily draw states into a relationship with one another. Furthermore, such individuals may be regulated by the laws of more than one state and thus belong to more than one state. Private international law is tasked with where and how to work out these collisions between laws. Hence, phenomena such as globalization and mass migration do not disturb the private-international-law paradigm; they chiefly intensify what is already inherent in it. It follows that overlapping identities, different kinds of membership in the state, lived membership - virtually all of the innovative ways of theorizing identity and citizenship-correspond to traditional private-international-law techniques and their interaction with public law." 33

Knop notes that "domicile", a common law test for jurisdiction, allows for individual choice, unlike the "two-way relationship" of nationality, which is "based on the acceptance of common values". ${ }^{34}$ It is striking, then, that Principle 2 of the Guiding Principles deliberately chose "domicile" over "nationality".

A final intriguing complexity arises if attention is given to regulation of transnational corporate conduct in areas beyond the jurisdiction of any state. ${ }^{35}$ For this, the international deep seabed mining regime under the UN Convention on the Law of the Sea [UNCLOS] offers food for thought. ${ }^{36}$ Here, we

30 Ibid

31 Ibid.

32 Karen Knop, “Citizenship, Public and Private” (2008) 71 Law \& Contemp Probs 309 at 319.

33 Ibid at 319.

34 Ibid at 320. See further Knop’s discussion of “commercial domicile” as a "test of an enemy alien”. Ibid at 325-327.

35 This part is drawn from Anna Dolidze and Sara Seck, "ITLOS Case No. 17 and the Evolving Principles for Corporate Accountability under International Law”, draft paper prepared for June 2013 Conference of the International Law Association's Committee on Non-State Actors, Vancouver, BC (on file with author; forthcoming as chapter in edited book, Brill).

36 See United Nations Convention on the Law of the Sea, December 10, 1982, online: UN <http://www.un.org/depts/los/convention_agreements/texts/unclos/UNCLOS-TOC.htm>;Seabed Disputes Chamber of the International Tribunal for the Law of the Sea, Advisory Opinion: Responsibilities and Obligations of States Sponsoring Persons and Entities with Respect to Activities in the Area (Case No. 17), February 1, 2011, online: ITLOS <http://www.itlos.org/file-admin/itlos/documents/cases/case_no_17/adv_op_010211.pdf > [Advisory Opinion] 
are concerned less obviously with the possibility of human rights violations, but rather with pollution of a global commons in an area of the world where the significance of citizenship rests upon whether a corporate entity has been sponsored. Exploration and exploitation activities in the deep seabed may be carried out in association with the International Seabed Authority [ISA] by "State parties or state enterprises or natural or juridical persons". ${ }^{37}$ For natural and juridical persons to be eligible to carry out such activities, they must meet two requirements: "First, they must be either nationals of a State Party or effectively controlled by it or its nationals. Second, they must be 'sponsored by such States'," a requirement that also applies to state enterprises. ${ }^{38}$ The rationale for the sponsorship requirement, according to the International Tribunal for the Law of the Sea [ITLOS] Advisory Opinion, is to ensure that entities "that are subjects of domestic legal systems" comply with obligations set out in [UNCLOS], "a treaty under international law which binds only States Parties thereto." 39 This is achieved by the application of ISA Regulations to these entities, and "implementation by the sponsoring States of their obligations" thus contributing to "the realization of the common interest of all States in the proper application of the principle of the common heritage of mankind." 40

The Advisory Opinion is clear that no State party is "obligated to sponsor an entity that holds its nationality or is controlled by it or by its nationals" as UNCLOS does not consider "links of nationality and effective control sufficient to obtain the result that the contractor conforms" with the relevant instruments. ${ }^{41}$ Instead, a "specific act emanating from the will of the State or States of nationality and of effective control" is required: "the decision to sponsor". ${ }^{42}$ Yet for a domestic law entity to apply for a contract in the Area and to continue as an active contractor in the Area, it must both "secure and maintain the sponsorship of the State or States of which they are nationals" and secure and maintain the sponsorship of a State that either "exercises effective control" or has a national that "exercises effective control" over the entity. ${ }^{43}$ This sponsorship requirement is not, however, applied to State parties (despite at least two assuming that it did), for "as subjects of international law, States Parties engaged in deep seabed mining under the Convention are directly bound by the obligations set out therein." 44

The implications of state sponsorship as discussed in the Advisory Opinion rest upon the premise that these states will regulate to ensure contractors do not harm the deep seabed, and the Advisory Opinion explores at length the content of potential responsibility and liability for sponsoring states. Of note for our purposes, however, is that in the opinion of Nauru, one of the states initiating this Advisory Opinion, the conclusion by the Deep Seabed Tribunal that all sponsoring states must regulate contractors imposed too harsh a burden on poor states with limited regulatory capacity, undermining the premise of equal participation by all states fundamental to the regime. Nauru, by contrast, would have preferred a contractual approach. ${ }^{45}$

Nauru's position arguably heightens the legal personality of corporate contractors under international

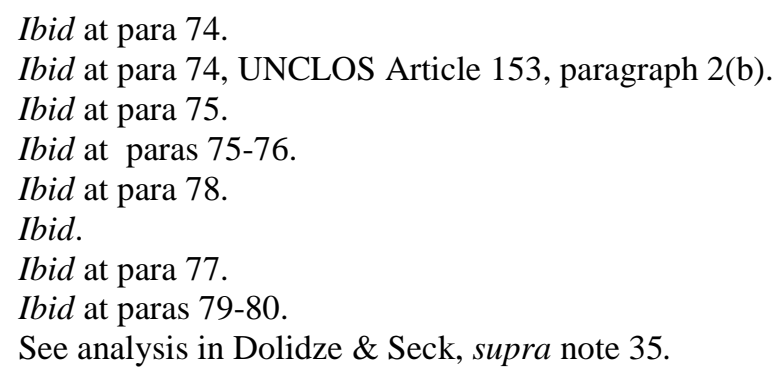


law, a position in line with the development of the corporate responsibility to respect under the Guiding Principles as will be discussed below. In terms of developing an understanding of corporate citizenship and non-citizenship, I would like to suggest that the deep seabed example complements the stories told above by reinforcing a hidden message: whether and to what extent corporate citizenship and noncitizenship matter depends in part on the regulatory capacity of the state. And regulatory capacity differs from state to state, from jurisdictional context to context, and from regulatory context to context. Indeed, this suggestion is supported by literature that suggests we make a mistake when we blindly idolize the state as the sole source of regulatory power in an interconnected transnational world. As Larry Cata Backer and others have argued, it may be equally, if not more accurate to view business enterprises as legal systems of their own accord, that then "shop" around to different jurisdictions for the "commodity" we know as state law that might best suit their global agendas. ${ }^{46}$

What might this mean for the quest for access to remedy in a world of transnational law? Importantly, if businesses "shop" for law, do they choose jurisdictions that allow them to escape legal liability and accountability when accused of human rights violations? Or do they seek jurisdictions that provide the legal certainty necessary to arrange business affairs in advance, irrespective of where legal liability falls? Might businesses shop for jurisdictions that provide the possibility of soft non-judicial remedy, perhaps in the form of mediation designed to help prevent problems from festering into liability issues? Or will businesses decide that, rather than shop for state law and legal institutions, or even state-based non-judicial mechanisms, they will instead design their own solutions in the form of company-level grievance or remedy mechanisms? As we shall see below, all possibilities are promoted under the Guiding Principles.

\section{CITIZENSHIP AND RIGHTS OF ACCESS TO REMEDY}

Having explored TNC citizenship, the paper will now briefly explore the implications of citizenship or non-citizenship for victims of human rights violations. As identified above, within the host state, a key question might be: does (or should) citizenship include a right to legally enforceable remedy against non-state actors operating within the state? Within the home state, a key question might be: is legally enforceable remedy against non-state actors within the state something that is or should be available to state citizens only or non-citizens as well? In practice, such remedy is often hard to achieve. For those who believe in law, this is a troubling situation.

The Guiding Principles touch upon this problem under Access to Remedy, noting in Principle 25:

"As part of their duty to protect against business-related human rights abuse, States must take appropriate steps to ensure, through judicial, administrative, legislative or other appropriate means, that when such abuses occur within their territory and/or jurisdiction those affected have access to effective remedy."47

\footnotetext{
46 Larry Catá Backer, “Governance without Government: An Overview and Application of Interactions Between Law-State and Governance-Corporate Systems” in Günther Teubner \& Joachim Zekoll, eds, Beyond Territoriality: Transnational Legal Authority in an Age of Globalization (Leiden: Brill Nijoff, 2012) 101 at 129, online: SSRN <http://ssrn.com/abstract=15-68934> [Cata Backer, “Governance without Government”]

47 Guiding Principles, supra note 4 at Principle 25.
} 
And in Principle 26:

"States should take appropriate steps to ensure the effectiveness of domestic judicial mechanisms when addressing business-related human rights abuses, including considering ways to reduce legal, practical and other relevant barriers that could lead to a denial of access to remedy." 48

Commentary to Principle 26 goes on to note the importance of effectiveness of judicial mechanisms for access to remedy, with the "ability to address business-related human rights abuses" being dependent upon "their impartiality, integrity and ability to accord due process." 49 The Commentary then highlights that "States should ensure that they do not erect barriers to prevent legitimate cases from being brought before the courts" - or at least, they should do this "where judicial recourse is an essential part of accessing remedy or alternative sources of effective remedy are unavailable." ${ }^{\text {"No }}$ The language here suggests the clear understanding that judicial remedy is not the only type of remedy in the toolkit, and clearly not the only one of value, an understanding that is in keeping with the increasing place given to mediation and alternate dispute resolution in domestic legal systems. Moreover, the types of remedies envisioned include "apologies, restitution, rehabilitation, financial or non-financial compensation and punitive sanctions (whether criminal or administrative, such as fines) as well as the prevention of harm through, for example, injunctions or guarantees of non-repetition." ${ }^{51}$ The remedy toolkit is expansive.

Commentary to Principle 26 notes that States:

should also ensure that the provision of justice is not prevented by corruption of the judicial process, that courts are independent of economic or political pressures from other State agents and from business actors, and that the legitimate and peaceful activities of human rights defenders are not obstructed.

The importance of the first part of this Commentary is evident in the ongoing Chevron/Ecuador litigation originally brought in US courts in the 1990s and dismissed in 2002 to the courts of Ecuador as the better forum for resolving the dispute, with Chevron (Texaco at the time) agreeing to satisfy any judgment. ${ }^{52}$ Twelve years later, enforcement of a US\$9.5 billion dollar judgment from the courts of Ecuador has been fought by Chevron as vigorously as possible wherever possible, including an unsuccessful attempt to get US courts to bar enforcement of the Ecuadorean judgment anywhere in the

\footnotetext{
Ibid at Principle 26.

Ibid at Commentary to Principle 26.

Ibid.

Ibid at Commentary to Principle 25.
}

52 Aguinda et al v. Texaco, Inc, 303 F $3 d 470$ (2d Cir 2002). See also Dan Bodansky, Judith Kimerling, Lucinda Low \& Ralph Steinhardt "Remarks: The Chevron-Ecuador Dispute: A Paradigm of Complexity", (2012) Vol 106 Proceedings of the American Society of International Law Proceedings(2012) 415; Texaco/Chevron lawsuits summary, online: Business \& Human Rights <http://www.businesshumanrights.org/Categories/Lawlawsuits/Lawsuitsregulatoryaction/LawsuitsSelectedcases/TexacoChevronlawsuitsreEcuador>. 
world. ${ }^{53}$ Most recently, a New York court has found that the long-sought judgment was "fraudulently obtained". ${ }^{54}$ This judgment is now under appeal, while the Supreme Court of Canada has agreed to hear an appeal as to whether Ontario courts have jurisdiction to enforce the Ecuadorean judgment against Chevron and wholly-owned subsidiary Chevron Canada. ${ }^{55}$

The importance of not obstructing the peaceful activities of human rights defenders also brings to mind much-discussed litigation arising out of oil exploitation in Nigeria, as well, indeed, as resource extraction conflicts that arise in many parts of the world. ${ }^{56}$ In 2009 a settlement was reached in which Shell agreed to pay $\$ 15.5$ million to the families of environmental activists Ken Saro Wiwa and other residents of the Ogoni region who had been tortured and killed by the Nigerian government. ${ }^{57}$ Yet, subsequent litigation against Shell over similar issues has resulted, after many years of litigation, in a USSC decision that has severely restricted the jurisdictional scope of the US Alien Tort Statute due to the presumption against extraterritoriality. ${ }^{58}$

A number of additional "[l]egal barriers" are identified in the Commentary to the Guiding Principles, including the attribution of legal responsibility among members of corporate groups under criminal and civil laws; a lack of access to home State court despite facing a denial of justice in the host state court; and barriers faced by certain groups such as indigenous peoples and migrants. ${ }^{59}$ Importantly the Commentary identifies "[p]ractical and procedural barriers" to access to judicial remedy, including the "costs of bringing claims"; challenges in "securing legal representation"; "inadequate options for aggregating claims or enabling representative procedures"; and a lack of state "resources, expertise and support" to investigate and prosecute human rights crimes. ${ }^{60}$ Moreover:

Many of these barriers are the result of, or compounded by, the frequent imbalances between the parties to business-related human rights claims, such as in their financial

53 Chevron Corporation v Naranjo, 667 F 3d 232 (2d Cir 2012).

54 Chevron Corporation v Steven Donziger, 11 Civ 0691 (US Dist Ct, Southern District of NY, March 4, 2014) online: Conflict of Laws <http://conflictoflaws.net/News/2014/03/chevron-decision.pdf $>$.

55 See Yaiguaje v Chevron Corporation, 2013 ONCA 758 (CanLII), leave to appeal to the SCC granted, online SCC $<$ http://www.scc-csc.gc.ca/case-dossier/info/sum-som-eng.aspx?cas=35682> .

56 Seck, "Kiobel", supra note 8.

57 Ibid; Complaint, Wiwa et al v Royal Dutch Petroleum Company et al, (Nov 1996), online Centre for Constitutional Rights: <http://ccrjustice.org/files/11.8.96\%20\%20Wiwa\%20Complaint.pdf>; Centre for Constitutional Rights, "Wiwa et al, v Royal Dutch Petroleum et al”, online: Centre for Constitutional Rights <http://ccrjustice.org/ourcases/currentcases/wiwa-v.-royal-dutch-petroleum>. The allegations were that Shell acted in concert with the Nigerian government. The settlement was without admission of wrongdoing.

58 Seck, "Kiobel”, supra note 8; Kiobel v Royal Dutch Petroleum 569 US (2013). See also “Agora: Reflections on Kiobel, Excerpts from AJIL and AJIL Unbound" (2014) online: ASIL

<http://www.asil.org/sites/default/files/AGORA/201401/AJIL\%20Agora-20Reflections\%20on\%20Kiobel.pdf> ; and "The Kiobel Case: the Supreme Court Review of Alien Tort Claims Act”, online: Business \& Human Rights $<$ http://www.business-humanrights.org/Documents/SupremeCourtATCAReview $>$. On human rights defenders more generally, see Report of the Special Rapporteur on the situation of human rights defenders, Margaret Sekaggya, UN HRC 19 Session, UN Doc A/HRC/19/55 (21 December 2011) at paras 60-87 and paras 124-126; Report of the Special Rapporteur on the rights of indigenous peoples, James Anaya, Extractive Industries and Indigenous Peoples, UN HRC $24^{\text {th }}$ Sess., UN Doc A/HRC/21/41 (1 July, 2013) at paras 19-25.

59 Guiding Principles, supra note 4 at Commentary to Principle 26

60 Ibid. 
resources, access to information and expertise. Moreover, whether through active discrimination or as the unintended consequences of the way judicial mechanisms are designed and operate, individuals from groups or populations at heightened risk of vulnerability or marginalization often face additional cultural, social, physical and financial impediments to accessing, using and benefiting from these mechanisms. ... ${ }^{61}$

Clearly, then, the Guiding Principles recognize that many hurdles face plaintiffs who seek judicial remedy for human rights violations. Indeed, this suggests that before turning to the transnational we might first look inward to ask whether, in a rich state like Canada, we can truly say that those who seek legal remedy for local violations of human rights are in a position to access justice. ${ }^{62}$ Certainly when it comes to violations of human rights with an environmental dimension (environmental justice claims), the answer given by many is a resounding no, which should give those of us who believe in law a moment's pause. ${ }^{63}$ While national human rights institutions may have the potential to address some host state justice claims, there is much work to be done. ${ }^{64}$

Turning to the transnational, arguably, the residual role given to the "home" state (arising upon a denial of justice in the host state) is underinclusive - why might the home state not equally be obligated to provide a forum if that is the forum of choice of the plaintiffs alleging human rights violations? Key examples of failures of legal remedy abound, from the infamous Chrevron litigation discussed above to Bhopal and Kiobel. Beyond what is identified in the UNGPs are other fundamental doctrines of private international law, premised on the inviolability of sovereignty and comity including the Mozambique doctrine's fixation with territory, and doctrines that prevent enforcement of foreign state's penal and tax laws. ${ }^{65}$ Re-conceiving sovereignty (and comity) in relational terms is a big - and as yet far from complete - task. ${ }^{66}$ Yet by not taking on the challenge, the failure to date of transnational legal remedy has created pressures for remedy in other forms, a subject to which I will now turn.

\section{TRANSNATIONAL NON-JUDICIAL RESPONSES}

Two notable features highlight the move away from state law in the Guiding Principles whether host or home, and the move toward a transnational legal pluralist realm: the emergence of the (non-legal)

61 Ibid.

62 See recent comments by Supreme Court of Canada Chief Justice Beverly McLachlin, online: Canadian Broadcasting Corporation <http://www.cbc.ca/news/canada/saskatoon/canada-s-top-judge-slams-inaccessible-justice-1.1306993> and Canadian Bar Association Report, Reaching Equal Justice (2013), online: CBA<

http://www.cba.org/cba/equaljustice/secure_pdf/Equal-Justice-Report-eng.pdf>.

63 See generally David R Boyd, The Right to a Healthy Environment: Revitalizing Canada's Constitution (Vancouver, Toronto: University of British Columbia Press, 2012); Danya Nadine Scott, "Situating Sarnia: "Unimagined Communities” in the New National Energy Debate”, (2013) 25 J Env L P 81.

64 See for example Meg Brodie, "Pushing the Boundaries: The Role of National Human Rights Institutions in the Operationalizing of 'Protect, Respect and Remedy' Framework” in Radu Mares, ed, The UN Guiding Principles on Business and Human Rights: Foundations and Implementation (Leiden, Boston: Martinus Nijhoff Publishers, 2012 ) 245.

65 See Seck, “Environmental Harm”, supra note 25.

66 See Karen Knop, “Re/Statements: Feminism and State Sovereignty in International Law” (1993) 3 Transnat’l L \& Contemp Probs. 293 and reference to this analysis together with insights from Third World Approaches to International Law (TWAIL) in Seck, “Unilateral Home”, supra note 21. 
corporate (business) responsibility to respect rights, and the layering of access to remedy mechanisms so as to include judicial and non-judicial, state-based and non-state-based, and even company-level grievance and remedy mechanisms.

Thus, according to the Guiding Principles, businesses are understood to be expected to engage in due diligence in order to both prevent and, in some cases, remedy, human rights harms. The business (corporate) responsibility to respect rights is presented in foundational Principle 11 as:

"Business enterprises should respect human rights. This means that they should avoid infringing on the human rights of others and should address adverse human rights impacts with which they are involved.”

The Commentary describes this responsibility as a "global standard of expected conduct for all business enterprises wherever they operate" that "exists independently of States' abilities and/or willingness to fulfil their own human rights obligations, and does not diminish those obligations. And it exists over and above compliance with national laws and regulations protecting human rights. ${ }^{\text {} 67}$ While phrased in permissive language (should, not shall), it is expansive in going "beyond" host state law, taking away the legitimizing power of host state irresponsibility for corporate misconduct.

The Commentary provides that to meet the corporate responsibility to respect, businesses must take "adequate measures" to prevent, mitigate and "where appropriate," remediate adverse human rights impacts. Importantly, "[b]usiness enterprises should not undermine States' abilities to meet their own human rights obligations, including by actions that might weaken the integrity of judicial processes." ${ }^{\text {"68 }}$ It remains unclear exactly what actions might fall within this category, although arguably "litigation strategy" designed to undermine existing transnational human rights remedy mechanisms could be of such character, an issue raised by the primary author of the Guiding Principles in relation to the expansive arguments of Shell in Kiobel. ${ }^{69}$

The jurisdictional scope of the business responsibility to respect is addressed in Principle 13 in an expansive way:

The responsibility to respect human rights requires that business enterprises:

(a) Avoid causing or contributing to adverse human right impacts through their own activities, and address such impacts where they occur;

(b) Seek to prevent or mitigate adverse human rights impacts that are directly linked to their operations, products or services by their business relationships, even if they have not contributed to those impacts. ${ }^{70}$

According to the Commentary to Principle 13, "business relationships" are "understood to include

67 Guiding Principles, supra note 4 at Commentary to Principle 11.

68 Ibid.

69 See John Ruggie, “Kiobel and Corporate Social Responsibility” (2012): online: Harvard Kennedy School

$<$ http://www.hks.harvard.edu/mrcbg/CSRI/KIOBEL_AND_CORPORATE_SO-CIAL_RESPONSIBILITY\%20(3).pdf>

70 Guiding Principles, supra note 4 at Principle 13. 
relationships with business partners, entities in its value chain, and any other non-State or State entity directly linked to its business operations, products or services."71 This again is an expansive jurisdictional scope of responsibility, extending far beyond understandings of corporate separate legal entities, and even beyond the more expansive idea of corporate enterprise, into the realm of contractual relationships and supply chains. Yet, in the public conscience, this is indeed how the popular press views the responsibility of business enterprises, or at least large ones in a position to exert power either to undermine or enhance respect for human rights of stakeholders such as workers, including those down the supply chain. ${ }^{72}$ Moreover, public conscience may yet map onto law if, as suggested by Radu Mares, consideration is given to tort law and the potential for liability for negligence where risks are foreseeable. ${ }^{73}$

In Principle 15, the Guiding Principles elaborate the "policies and processes" that business enterprises should have in place (as "appropriate to their size and circumstances") in order to meet their responsibility to respect:

(a) A policy commitment to meet their responsibility to respect human rights;

(b) A human rights due-diligence process to identify, prevent, mitigate and account for how they address their impacts on human rights;

(c) Processes to enable the remediation of any adverse human rights impacts they cause or to which they contribute. ${ }^{74}$

The operational principles under the corporate responsibility to respect expand upon the requirements in Principle 15. Of note under Principle 17, the Commentary states clearly that human rights due diligence "can be included within broader enterprise risk-management systems, provided that it goes beyond simply identifying and managing material risks to the company itself, to include risks to rightsholders." 75 However, as observed by Nicola Jägers, in order for a company to identify risks to rightsholders and be accountable to them in the "courts of public opinion", if not in law, it is also necessary for potential rights-holders or NGOs acting on their behalf to access information often held only by the company. $^{76}$

Also striking in the Commentary to Principle 17 is the apparent clear distinction between the conduct of human rights due diligence and legal liability. According to the Commentary, while "[c]onducting appropriate human rights due diligence should help business enterprises address the risk of legal claims

71 Ibid at Commentary to Principle 13.

72 This understanding was clearly evident in relation to the Bangladesh factory fire of the summer of 2014, and has similarly been evident in other similar contexts. See analysis of the Gap in Catá Backer, “Gap”, supra note 14. See also Karin Lukers, "Human Rights in the Supply Chain: Influence and Accountability” in Radu Mares, ed, The UN Guiding Principles on Business and Human Rights: Foundations and Implementation (Martinus Nijhoff Publishers, 2012 ) 151.

73 Radu Mares, "Why the Core Company Should Act When Affiliates Infringe Human Rights” in Radu Mares, ed, at 192. A version of this argument is at the heart of the Hudbay litigation, supra note 27.

74 Guiding Principles, supra note 4 at Principle 15.

75 Ibid at Commentary to Principle 17.

76 Nicola Jägers, “Will transnational private regulation close the governance gap?” in Surya Deva \& David Bilchitz, eds, Human Rights Obligations of Business: Beyond the Corporate Responsibility to Respect? (Cambridge University Press, 2013) 295, at 300. 
against them by showing that they took every reasonable step to avoid involvement with an alleged human rights abuse," "business enterprises conducting such due diligence should not assume that, by itself, this will automatically and fully absolve them from liability for causing or contributing to human rights abuses., ${ }^{77}$ Further, according to Principle 23:

In all contexts, business enterprises should:

(a) Comply with all applicable laws and respect internationally recognized human rights, wherever they operate;

(b) Seek ways to honour the principles of internationally recognized human rights when faced with conflicting requirements;

(c) Treat the risk of causing or contributing to gross human rights abuses as a legal compliance issue wherever they operate. ${ }^{78}$

Importantly, and as noted in Principle 15, the corporate responsibility to respect rights includes a responsibility to play a role in providing access to remedy to victims of human rights violations in some circumstances. This is expanded upon in Principle 22, which provides: "Where business enterprises identify that they have caused or contributed to adverse impacts, they should provide for or cooperate in their remediation through legitimate processes." ${ }^{, 79}$ Yet while "[o]perational-level grievance mechanisms ... can be one effective means of enabling remediation" provided "certain core criteria" found in Principle 31 are met, the situation is different should "crimes" be alleged, in which case "cooperation with judicial mechanisms" should be the response. ${ }^{80}$

In sum, then, the business responsibility to respect rights as elaborated in the Guiding Principles represents a move into the realm of transnational legal pluralism and away from obsession with host state law as the sole normative order of relevance. Notably, it is not a move into the land of public international law, with its claims of direct corporate responsibility under international law for violations of egregious norms (at least), including through aiding and abetting or complicity with sovereign host state violators. ${ }^{81}$ Rather, the responsibility is framed in non-legal terms arising from societal expectations, although whether or not legal significance might ultimately attach - or even currently exists depending on the content of a particular state's law - remains an open question. ${ }^{82}$

The evidence of a transnational legal pluralist shift away from preoccupation with state law is also evident in terms of remedy as elaborated in Principles 25-31 of the Guiding Principles. As noted earlier,

77 Guiding Principles, supra note 4 at Commentary to Principle 17.

78 Guiding Principles, supra note 4 at Principle 23.

79 Ibid at Principle 22. The Commentary to Principle 22 clarifies that this responsibility does not extend to situations where the "business enterprise has not caused or contributed to" the adverse impacts, even if they are "directly linked to its operations, products or services by a business relationship", although it may play a role in remediation if it chooses to.

$80 \quad$ Ibid at Commentary to Principle 22.

81 See e.g. International Commission of Jurists, Report of the ICJ Expert Legal Panel on Corporate Complicity in International Crimes,(2008), online: ICJ <http://www.icj.org/report-of-the-international-commission-of-jurists-expertlegal-panel-on-corporate-complicity-in-international-crimes/>

82 See Peter Muchlinski, "Implementing the New UN Corporate Human Rights Framework: Implications for Corporate Law, Governance and Regulation” (2012) 22:1 Business Ethics Quarterly 145; Mares, supra note 73. See also decisions cited above in footnote 27. 
while foundational Principle 25 and operational Principle 26 expound upon the duty to the state to provide access to remedy, and the role of judicial mechanisms in this, Principles 27-31 go beyond state law, highlighting a role for state-based non-judicial grievance mechanisms (Principle 27), non-statebased grievance mechanisms (Principle 28), operational-level grievance mechanisms (Principle 29), industry, and multi-stakeholder and other collaborative initiatives (Principle 30). ${ }^{83}$ "Effectiveness Criteria” are then outlined in Principle 31: legitimate, accessible, predictable, equitable, transparent, rights-compatible, a source of continuous learning, and, for operational grievance mechanisms, based on engagement and dialogue. ${ }^{84}$

Without delving further into the details of these, a few key points are in order. First, the detailed attention given to non-judicial mechanisms in the Guiding Principles suggests both that additional guidance was felt necessary in this realm, and that these types of mechanisms are increasingly becoming important in the business and human rights context. Much evidence of this exists, ${ }^{85}$ whether due to the development of state-based processes like the National Contact Point for the Organisation of Economic Cooperation and Development's Guidelines for Multinational Enterprises ${ }^{86}$ or Canada's Corporate Social Responsibility Counsellor for the Extractive Industries Operating Internationally; ${ }^{87}$ or non-statebased such as the International Finance Corporation's Compliance Advisor Ombusdperson. ${ }^{88}$ Moreover, many of these processes have been updated to reflect the new expectations of human rights due diligence incorporated in the 2011 Guiding Principles. ${ }^{89}$

With regard to operational-level grievance mechanisms, the Guiding Principles are clear that engaging affected stakeholders about the design and process would increase commitment to seeing the

83 Guiding Principles, supra note 4.

84 Ibid at Principle 31.

85 Elisa Morgera, Corporate Accountability in International Environmental Law (Oxford: Oxford University Press, 2009) at Chapters 10 \& 11; Natalie L. Bridgeman \& David B. Hunter. "Narrowing the Accountability Gap: Toward a New Foreign Investor Accountability Mechanism” (2008) Georgetown International Environmental Law Review 188; Daniel D. Bradlow, "Private Complainants and International Organizations: A Comparative Study of the Independent Inspection Mechanisms in International Financial Institutions” (2005) Georgetown Journal of International Law 405.

86 See OECD, “OECD Guidelines for Multinational Enterprises”, (Paris: OECD Publishing, 2011) available online” OECD < http://dx.doi.org/10.1787/9789264115415-en, and for example Canada’s National Contact Point: http://www.international.gc.ca/trade-agreements-accords-commerciaux/ncppcn/index.aspx?lang=eng\&menu_id=1\&menu=R>; see also Catá Backer, “Governance without Government” supra note 46 at $133-138$.

87 See Seck, “Canadian Mining”, supra note 21 at 65 (on the Canadian experience with the CSR counsellor for the extractive industries). This mechanism is under review.

88 Morgera, supra note 84 at 216-222; Compliance Advisor Ombudsman, “Our Mandate”, online: CAO <http://www.caoombudsman.org/>

89 For example, the OECD MNE Guidelines and IFC Sustainability Policy were both updated in 2011. IFC, IFC's Sustainability Framework, available online: IFC $<$ http://www1.ifc.org/wps/wcm/connect/Topics_Ext_Content/IFC_External_Corporate_Site/IFC+Sustainability/Sustaina bility+Framework/>; IFC Sustainability: Events and Milestones, available online: IFC

$<$ http://www1.ifc.org/wps/wcm/connect/Topics_Ext_Content/IFC_External_Corporate_Site/IFC+Sustainability/Sustainability+Framework/The+2009-

2011+Review+and+Update/Events+and+Milestones/>; OECD, "2011 Update of the OECD Guidelines for Multinational Enterprises - Comparative table of changes made to the 2000 text”, available online: OECD $<$ http://www.oecd.org/daf/inv/mne/49744860.pdf $>$. 
mechanism become a success. ${ }^{90}$ Furthermore: "[s]ince a business enterprise cannot, with legitimacy, both be the subject of complaints and unilaterally determine their outcome, these mechanisms should focus on reaching agreed solutions through dialogue. Where adjudication is needed, this should be provided by a legitimate, independent third-party mechanism." ${ }^{91}$ Examples of company-level grievance mechanisms, as well as company funded but independent remedy mechanisms are increasingly emerging, as shared learning encourages new attempts. ${ }^{92}$ Yet, how to reconcile the outcomes of these non-judicial, non-state, non-law mechanisms with the rule of state law remains contested, highlighted by controversy over requirements to sign legal waivers to prevent future civil claims as a condition of accessing non-judicial remedy. ${ }^{93}$

Fascinatingly, the Guiding Principles lump together under Principle 28's discussion of non-statebased, non-judicial mechanisms both those associated with business and industry associations, and international and regional human rights law mechanisms that might focus on violations of the state duty to protect. This is a striking positioning. In state-centric international law, human rights mechanisms, whether international or regional, are a "higher legal order" than the state, and business enterprises, which as creatures of statute and creations of states should surely rank lower down the chain or hierarchy. But if we have moved beyond state-centric international law into a realm where non-state actors such as businesses, civil society NGOs, and indigenous peoples, all as participants in international legal process, can create their own mechanisms to resolve disputes, either collaboratively or alone, and if these mechanisms are seen as no different from those created by states for themselves, then this positioning becomes easier to understand, if not easier to accept by international human rights lawyers. Whether or not we choose to call these developments law, drawing upon international legal theories influenced by constructivist strands of international relations, ${ }^{94}$ and scholars who speak of transnational law, ${ }^{95}$ or choose not to call them law at all, does not particularly matter from the perspective of victims who seek access to justice. (If effectiveness criteria are met, including legitimacy, etc, may we not call it law?) But it does matter when trying to understand the relationship between decisions arising out of different legal orders that may or may not be in tension with one another. Within one state, it is clear what the relationship is between an administrative tribunal and the courts, guided by understandings of

90 Guiding Principles, supra note 4 at Principle 31.

91 Ibid.

92 See e.g. ACCESS Facility, describes itself as: “an independent platform for a broad range of stakeholders to learn, explore, share ideas, forge relationships, and find solutions that work for them.” See http://www.accessfacility.org/ and its Case Study Library with 185 entries featuring a wide variety of non-judicial grievance mechanisms, including state and non-state-based (accessed April 4, 2014).

93 Catherine Coumans, MiningWatch Canada, "Brief on Concerns Related to Project-Level Non-Judicial Grievance Mechanisms. Data derived from work by MiningWatch Canada and partners on the Porgera Joint Venture mine in Papua New Guinea and the North Mara Gold Mine in Tanzania,” Prepared for Expert Meeting: "Sharing experiences and finding practical solutions regarding the implementation of the UNGP's effectiveness criteria” (The Hague, April 3-4, 2014). See also UN Office of the High Commissioner for Human Rights, "Letter, RE: Allegations regarding the Porgera Joint Venture remedy framework” online: BHR < http://business-humanrights.org/media/ohchr-porgera-joint-ventureletter-aug-2013.pdf>.

94 Jutta Brunnee, \& Stephen J. Toope, “International Law and Constructivism: Elements of an Interactional Theory of International Law” (2000) 39 Colum J Transnat'l L 19

95 Peer Zumbansen, “Transnational Law, Evolving”, in Jan Smits, ed, Elgar Encyclopedia of Comparative Law (2012), citing Philip Jessup, Transnational Law (1996). See also Jägers, supra note 76. 
the "rule of law." Within private international law, foreign courts must "talk" to one another when called upon to recognize and enforce foreign judgments. Yet, it is not clear how these non-state mechanisms, whether foreign state-based or company-level can "talk" to the courts of home or host states. Will this reinforce or undermine the rule of law? Will host states that lack capacity be incentivized to develop it? Or will necessary resources be drawn away? What does this mean for the possibilities of transnational justice?

Frustration over the challenge of access to remedy under the Guiding Principles has led to calls at the UN Human Rights Council for the study of a "binding” international corporate accountability treaty. ${ }^{96}$ Beyond the Guiding Principles is a further development that must be noted: the rise of people's tribunals, designed to "try" corporations in absentia. ${ }^{97}$ How are we to understand these except as expressions of frustration over the inability of law to provide international, domestic or transnational justice?

\section{CONCLUSIONS}

This paper first reflected on the question of who is a citizen or non-citizen by examining the rights and obligations of transnational corporate actors, and the problem of governance gaps created by globalization that make the achievement of accountability for transnational corporate wrongdoing in the human rights context challenging. The paper then reflected on the meaning of citizenship by asking whether it should be understood to include rights of access to remedy against transnational non-state actors within both host and home state courts. Finally, the paper highlighted the extent to which the Guiding Principles move beyond state-centric international law and into a realm of transnational legal pluralism, with corporate responsibility understood expansively in scope but not as law, and remedy understood expansively in form but challenging to achieve as legally binding accountability.

It is too early to say whether the polycentric governance framework of the Guiding Principles will prove to be an effective way to providing access to remedy for victims of alleged corporate human rights violations in a transnational context. Having said this, one conclusion can clearly be drawn: if lawyers continue to advise corporate clients to engage in never-ending procedural maneuvers that sidestep the substance of the claims being brought forward, ${ }^{98}$ then the possibility of transnational justice and corporate accountability is in fact an illusion, a magic trick. Critically, we could conceptualize legal rights and legal obligations as crossing borders, rather than inherently limiting them with understandings of firm territorial borders created by statehood and guarded by sovereignty. Yet while in theory we could conceptualize both rights and obligations as crossing borders, in practice we do not. Why is this? One of the reasons may have to do with our unwitting ongoing "performance" of the boundaries of sovereignty, even by those who attempt to talk persuasively about "extraterritorial" human rights obligations of states. $^{99}$ Notably, in the corporate accountability context, we do not speak of

\footnotetext{
96 “Binding Treaty,” online Business and Human Rights Resource Centre < http://business-humanrights.org/en/bindingtreaty>

97 See e.g. Guatemala, online Health Tribunal <http://healthtribunal.org/>.

98 See e.g. the Chevron/Ecuador; Shell/Nigeria; and Bhopal examples - the most notorious of many such cases.

99 See e.g. "Maastricht Principles on the Extraterritorial Obligations of States", online: ETO Consortium <http://www.etoconsortium.org/en/library/maastricht-principles/>. Nick Blomley’s recent contribution "Performing
} 
"extraterritorial" corporations, but rather of transnational corporations or multinational enterprises engaged in foreign investment.

It is possible that private international law offers potential for moving beyond this limitation, at least if the "Gaian tradition" is adopted in which, according to Karen Knop, "the status of 'citizen'...denotes membership in a community of shared or common law, which may or may not be identical with a territorial community." 100 In the realm of public international law we can find a version of this spirit in the driving force behind the regime governing international deep seabed mining in the Area beyond the jurisdiction of any state. Designed to treat the deep seabed as the common heritage of humankind, the deep seabed regime was fundamentally about all states, whether rich or poor, sharing equitably in resource exploitation of the deep seabed. Yet the ITLOS decision described briefly above appears not to appreciate that equitable participation may necessitate differential treatment due to the reality that some states have more capacity to regulate than others. The solution should not have been to require all states to regulate or to regulate at the same level, but rather to ensure that all sponsoring states - whether due to the nationality of the contractor or effective control over the contractor - do their fair share.

Ultimately, this paper suggests that if we are concerned that the increasing role played by nonjudicial mechanisms in the business and human rights context may undermine host state rule of law and make legal remedy in the transnational human rights context increasingly irrelevant, then we must revisit understandings of sovereignty and territory as well as corporate legal personality that underscore contemporary interpretations of private international law and corporate liability doctrines. We must avoid the "e-word" and write the reality of transnational interconnectedness and mutual responsibility into our legal doctrines. If we fail to do so, what most lawyers understand as law may increasingly become irrelevant.

Property: Making the World” (2013) 26 Can JL \& Jur 23 has much to offer in this regard. See Sara Seck, "The Spatial and Temporal Dimensions of Sovereignty, Extraterritoriality and Human Rights" (Paper delivered at the Law on the Edge Conference Vancouver, BC, July 2013).

100 Knop (2008), supra note 32 at 310 citing JGA Pocock, “The Ideal of Citizenship Since Classical Times” (1992) 99 Queen's Q 33 at 41. 